\title{
ELITE AMBIGUITY TOWARDS \\ INTERNATIONALIZATION? \\ THE CASE OF NORWAY
}

TRYGVE GULBRANDSEN ${ }^{1}$

\begin{abstract}
Norway has traditionally had an ambiguous relation to international cooperation. Norway has on the one hand been an active member of United Nations and NATO and has signed several international treaties and agreements. On the other hand Norwegian voters have in national referenda twice turned down government proposals to join the European Union. At both occasions a majority of the elites were in favor of EU membership. Recent electoral studies have demonstrated that voters' support for EU has been further reduced since the latest referendum. An elite survey conducted in 2015 showed that also among the elites backing of EU has been reduced, particularly among top leaders within private business. Findings reported in this article do not indicate that the dominant elites are particularly concerned with the lack of codetermination accompanying the non-member status. The decreasing endorsement of EU among Norwegian elites is probably a result of a pragmatic assessment that Norway manages quite well as a non-member and of a certainty that negative opinions in the population forbid any attempt to take up the EU-issue again.
\end{abstract}

KEYWORDS: Elite attitudes towards internationalization, ambiguity, EU, international treaties

Norway has since World War II had an ambiguous relation to international cooperation. One the one hand, Norway is an active member of a large number of international organizations, first of all of United Nations. Norway was one of the 50 nations that signed the UN-treaty in 1945 and thus is one of the

1 Trygve Gulbrandsen is research professor at the Institute for Social Research, Oslo; e-mail: trygve. gulbrandsen@samfunnsforskning.no 
basic members. Norway has repeatedly stated that the UN is a cornerstone of Norwegian foreign policy.

On the other hand, Norway joined the Western Alliance (NATO) with skepticism, both on the right and left side of the political landscape. Some politicians in the Conservative Party and the Liberal Party were worried about national sovereignty. On the left side NATO-membership met resistance from communists and the left wing of the ruling labor party. The outcome was a compromise on NATO amongst the elites (except the radical left) which elevated security policy above partisan politics (Østerud 2007).

Norway has signed several international treaties which are binding for Norwegian policies, inter alia international human rights conventions, various environmental agreements and the international agreement which established the World Trade Organization. The human rights conventions are partly incorporated into Norwegian law and binds Norwegian legal interpretation to supranational court decisions. The cooperation through the World Trade Organization also implies that Norway is bound by international rules. Norwegian authorities entered all these agreements convinced about their significance for international trade and relations, but conscious about the accompanying bindings on Norwegian politics. However, during the latest two decades there has been a growing criticism of these effects (Østerud, Engelstad and Selle 2003). Leading Norwegian academics, in particular, have claimed that the international treaties have led to a "judicialization" of Norwegian politics. More and more policy questions are decided by courts, national or supranational, based upon the binding international treaties, and less room is left for decisions by the national politicians.

Norway has a highly open economy where about 40 per cent of Norwegian products and services are exported, making Norway dependent upon access to international markets, first and foremost in Europe. Nonetheless, twice the Norwegian voters have turned down in national referendums - in 1972 and 1994 - government proposals to join the European Union. In contrast Denmark joined EU in 1973 and Finland and Sweden in 1995. At both occasions the majority of the political and economic elites and the central mass media were strongly in favor of EU membership, while large groups of the population were opposed, backed by rural elites and left political parties. The outcome of the two referenda unsettled the political landscape in Norway for a long period afterwards. For instance, the election result in 1972 led to a number of changes in the political parties.

The opposition against EU was spurred on the one hand by a widespread fear of loss of control of Norwegian natural resources. The fisheries were unwilling to share Norwegian fish resources with fishing vessels from EU countries. The agricultural sector insisted on continued national preferential treatment to 
compensate for the difficult 'arctic' conditions of agricultural production. On the other hand, left wing parties and groups expressed strong skepticism to what was perceived as a liberalistic dominance within EU.

But the opposition against EU also had historical roots. Since the 19th century a tension between centre and periphery has been a crucial cleavage in Norwegian politics (Rokkan 1987). At the turn of the 19th century several popular movements emerged, like the language movement, the teetotal movement and the Christian lay movement. These popular movements were to a large extent rooted in rural areas. Their leaders formed a national-liberal political alliance with small business owners, farmers, teachers and liberal professions also strongly represented in the rural areas. These rural groups and movements were opposed to elite civil servants and business elites in the capital and other large cities. This historical cleavage was manifested both in the 1972 and the 1994 referenda with the pro-EU centre and the anti-EU periphery representing each side. Since the 1994 referendum Norwegian politicians have abstained from taking up the EU issue again.

As a substitute for full EU membership Norway instead signed the treaty of the European Economic Area (EEA). EEA is a treaty between the EU-countries and the three EFTA-countries Iceland, Liechtenstein and Norway which gives the EEA-countries access to the inner market of EU. At the same time it gives EU a significant role in the EEA-countries' legislation. Norway's management of its resources, including oil and gas, is challenged by the EU. The rules that are considered as necessary for the management of scarce authorities by Norwegian authorities are seen as restrictions on competition by the EU. Therefore Norway is under both political and legal pressure from the EU to abandon its national prerogatives to manage its natural resources (Østerud 2007).

Göncz (2017) has discussed different theoretical models for describing the institutional setting of the European Union, particularly federalism versus intergovernmentalism. None of these models are quite relevant for describing the particular relation Norway as a non-member has to EU. The Norwegian scholars Eriksen and Fossum (2015:239) have claimed that states like Switzerland and Norway are increasingly closely associated to a constantly changing and integrating entity over which they have no formal say. These countries relinquish sovereignty and this is not compensated through co-determination. The two scholars argue that EU's closely associated non-members (including Norway) exist under what they describe as a form of self-inflicted hegemony, with EU as the hegemon.

There is considerable skepticism toward the EEA treaty within parts of the labor movement and among groups affiliated with the fisheries and the agricultural sector. 
Despite the dilemmas and tensions which accompany Norway's international participation an elite study which was conducted in 2000 showed that Norwegian elites nonetheless exhibited a strong support for EU (Gulbrandsen et al. 2002). 74 per cent of the Norwegian top leaders who participated in the study stated that they probably would have voted for EU-membership if a new referendum was organized. In an electoral study which was carried out in 2001 only 41 per cent of the voters reported that they would have voted for joining EU (Aardal 2003).

Since the turn of the millennium Western societies have been confronted with several serious challenges, inter alia climate changes, a huge refugee crisis, and not the least the international financial crisis in 2007, which primarily had its origin in USA. The finance crisis caused severe problems in several EU countries, like increasing unemployment, shrinking welfare budgets and national debt. The question is whether these developments have affected Norwegian elites' support for international cooperation and supranationality. Have the shortcomings of international capitalism and EU's profound problems moved Norwegian top leaders to become more skeptical towards EU? In other words, were Norwegian elites in 2015 less willing to join EU than fifteen years earlier? Were the elites in 2015 concerned about loss of national authority to supranational institutions as the result of having entered into binding international treaties? Which elite groups were most international and which elites were most reserved against internationalization?

Above I showed that the attitudes of Norwegian citizens to membership in international organizations as EU and NATO have been related to basic cleavages and issues in Norwegian politics. To what extent is also the international orientation of Norwegian elites today related to these cleavages?

\section{CLEAVAGES AND ISSUES IN NORWEGIAN POLITICS}

Historically the political parties in Norway and citizens' electoral decisions have been aligned along three basic cleavages and political issues (Rokkan 1987; Aardal 2003). One central issue has been the role and scope of the state. Closely related to this issue is the extent of economic redistribution through taxes and a solidarity based income politics. The two biggest political parties in Norway - the Conservative Party and The Labor Party represent each side of this private - public cleavage. Another significant issue concerns the securing of settlement and acceptable standards of living in rural areas through subsidized prices on agricultural products and through economic transfers, - the centre - 
periphery cleavage. Thirdly, traditionally also the position of religious values in the Norwegian society was an important political issue and an origin to several political conflicts. An increasing secularization in the Norwegian society has, however, limited the political importance of this religious dimension. A testimony of which is that the Christian People's Party received only 4 per cent of the votes in the recent parliamentary election. During the latest decades the emergence of the environmental movement has brought in the conflict between growth and protection as an important dividing line in Norwegian politics. Finally, as in several other European countries immigration has become a significant and heated political issue. The Progress Party, a right wing populist party, has grown to be the third largest party in Norway, first and foremost based upon their strong opposition to immigration, particular from the third world.

In the following I will examine to what extent and how the elites' international orientation is related to three of these cleavages in Norwegian politics: (1) The Private - public dimension, (2) the centre - periphery dimension, and (3) the immigration issue.

\section{DATA AND METHOD}

In the following I shall attempt to answer the questions which were formulated above by help of data from a study of elites in Norway which was carried out in 2015, The Norwegian Leadership Study 2015. The Norwegian Leadership Study 2015 was a survey of a net sample of 1352 Norwegian top leaders within ten sectors of the Norwegian society: (1) Politics (members of parliament, state secretaries, mayors of the largest municipalities), (2) civil service, (3) culture, (4) mass media, (5) private business, (6) civic/voluntary organizations, (7) universities and large research institutes, (8) police and courts of justice, (9) military services, and (10) the church. The Leadership Study was conducted by Institute for Social Research in collaboration with Statistics Norway. The response rate of the survey was 71.5. The purpose of the Leadership Study 2015 was to examine the social background and careers of Norwegian top leaders, their relationships to each other, their attitudes to key policy issues, their lobbying, etc.

As measures of the attitudes of the Norwegian elites towards internationalization I have first used the answers to a question about what they would have voted if a new referendum about EU-membership was held. This is the same question which was used in the elite study in 2000, giving me the possibility to examine whether the share of EU sympathizers has changed during the latest fifteen 
years. While the members of parliament were asked this question in 2000, in 2015 only state secretaries and selected mayors were requested to state their opinion on this issue.

I have used the replies to this question to construct two groups: (1) Proponents and (2) opponents of EU. I have then located these two groups along the three selected political dimensions in Norwegian politics.

Secondly, the top leaders were asked, as in the 2000 survey, to consider whether national self-determination is too weak.

Thirdly, they were requested whether the national authority of the Norwegian parliament and government may be weakened if Norway adopts international legislation within the five following areas: (1) International trade, (2) international law of the sea, (3) international environmental protection, (4) international penal law, and (5) international human rights. The leaders were given three response alternatives: (1) A big possibility, (2) little possibility, (3) no possibility. The replies to these questions were distributed equally. Based upon these replies I have therefore constructed two groups among the elites: (1) 'Internationalists' who do not fear that signing international treaties undermine national authority, and (2) 'nationalists' who do believe that such treaties weaken the power of national authorities. All respondents who scored 1 on each of the five questions were defined as nationalists. Respondents with all other combinations of answers were defined as internationalists. I have then located these two groups along the three selected dimensions in Norwegian politics.

As a measure of the elites' stance on the private - public issue I constructed an index based upon respondents' opinions regarding the following four statements: (a) 'It is more important to extend public services than to reduce taxes'; (b) 'In Norway one should put stronger emphasis upon privatisation and a smaller public sector'; (c) 'State influence on private business should be reduced'; (d) 'In Norway we have come far enough as to the reduction of economic inequalities. The index has values from 1 to 5 . Value 5 indicates support for an active and intervening state, and value 1 denotes that the respondents prefer more privatization and less extensive public services. On average the Norwegian elites scored 3.25 on this index, a score which indicates that the elites are moderately endorsing an active state and continued redistribution of incomes.

The elites' position in the political debate about support of rural areas in Norway was measured in the following manner: They were asked to place themselves on a scale from 0 to 10 where 0 indicates that central authorities pay too little attention to the rural areas of Norway and 10 means that central authorities pay too much attention to these areas. On average the elites scored 5.6 on the scale. This score means that elites in general believe that the rural 
areas receive neither too much nor too little attention. This probably implies that the elites are satisfied with the profile of the present regional policy.

To survey the top leaders' attitudes towards immigration they were again requested to rank themselves on a $0-10$ scale. In this scale 0 signifies that the government should make it easier for immigrants to get access to Norway, and the value 10 means that there should be an even stronger limitation of the number of immigrants to Norway. On average the elites scored 4.4 on this scale, indicating a certain sympathy for a more lenient immigration policy. In comparison, an electoral study which was carried out in 2013 showed that the population on average scored 6.7 on the same scale (Aardal and Berg 2015). In other words, the population wishes more strict immigration policies than the elites do. In the Leadership study the politicians who belonged to the right wing populist Progress Party scored 8.2 on this scale, demonstrating their extreme stance on this issue.

\section{RESULTS}

In the 2015 survey 59 percent of the national top leaders confirmed that they would have voted in favor of joining EU if a new referendum was held. This is a clear reduction compared to what the respondents stated in the 2000 elite study. At that time 74 per cent would have voted for EU membership. In comparison, also among the voters support for EU has declined since the start of the new millennium. In the aforementioned electoral study in 2001 (Aardal 2007) a sample of the population scored 4.5 on a scale where the value 10 expresses that Norway should absolutely become member of EU, and the value 0 the opposite. In another electoral study in 2013 the voters on average scored only 2.9.

What are the explanations of the decline in elite support for EU? Has the EU-crisis scared the Norwegian elites away from EU? Alternatively, the decline may be a result of an emerging perception among Norwegian elites that the EEA agreement in reality has weakened Norwegian sovereignty, cf. the analysis of Eriksen and Fossum (2015) mentioned above. It is also possible that the diminishing support of EU rather represents an acknowledgment that Norway manages well outside EU, and that the EEA agreement is sufficient for regulating the country's relationship to EU. Such an acknowledgement may have been bolstered by the knowledge that the population today is less willing than ever to back a new application for EU membership. It is difficult to establish which of these explanations are most relevant, since we have not asked the top leaders about their arguments for or against EU. 
We may possibly learn somewhat more about the reasons for the decline in elite support for EU by examining the distribution of potential pro EU votes between the various elite groups. Figure 1 shows the percentage of 'would be' pro EU votes within the various elite groups. It demonstrates that there were clear differences in EU support between the various elite groups in Norway in 2015. In the one end only 42 per cent of the top leaders in the main institutions and organizations within the culture sector could imagine joining EU.

Figure 1. Would have voted for EU. Percentages

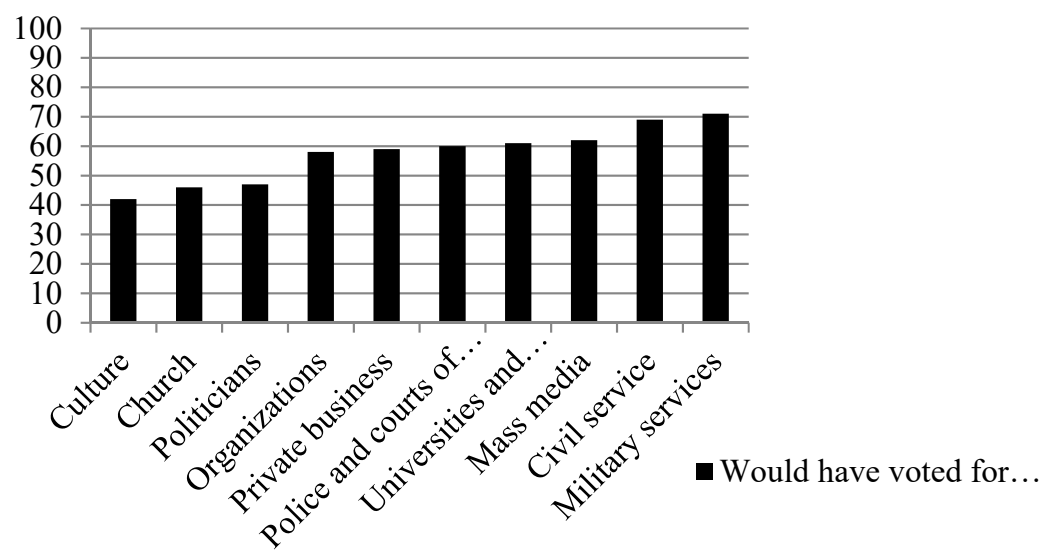

Also among church leaders (46 per cent) only a minority was intent on voting for EU membership in 2015. In 200060 per cent of top leaders within the culture sector would have voted for EU and only 50 per cent among the church leaders. In other words, the decline in EU support has been more pronounced among the culture elites.

The church leaders and the elites within the culture sector have previously distinguished themselves as belonging to the left side in the political landscape (Gulbrandsen and Engelstad 2005). They support an active welfare state and argue in favor of continued redistribution of incomes. That many top leaders within these two sectors show reservation to EU membership indicates that their opinions are rooted in a basic skepticism towards the political profile of EU.

In the other end of the scale we see that top leaders within the military services (71 per cent) and the civil service (69 per cent) primarily were in favor of joining EU. The percentage of top military officers who would have voted for joining EU is down from 90 in 2000. Among the senior civil servants the reduction was 
more moderate, from 79 to 69 per cent. In other words the members of the civil service elite seem to have been only moderately worried about EU's governance problems and EU's power. Both of which elite groups already have extensive contact with EU and other European nations. For them joining EU may be seen as a natural extension of the present relations. They may also be interested in the possibilities for more codetermination which will accompany a full membership status.

In 2000 about 51 per cent of the politicians (mostly members of parliament) were EU supporters. Among the few politicians included in the 2015 survey 47 per cent declared that they would have voted in favor of EU membership. Because so few politicians were posed the question of EU-membership in 2015, it is not possible to compare these two percentages. Nonetheless, the 2015 result may indicate that EU attitudes among politicians have changed less than among other groups.

The strongest decline in approval of EU between 2000 and 2015 took place among top leaders within private business - from 90 to 59 per cent. The strong decline of potential pro EU votes within the private business elite may be due to a growing understanding that business interests are best served with continued national control of vital resources like oil, gas, hydropower, and fish. I.e. a growing number of business leaders may prefer that Norway maintain the EEA agreement, in spite of its limitations. Business leaders want access to international markets. But they also want to continue receiving various forms of public support which can alleviate the pressures of international competition. Such a stance is in line with a 'both-and' attitude towards public goods and subsidies which is prevalent among private business leaders in Norway. They may ideologically be opposed to the Norwegian welfare state and prefer more market solutions. And they may praise a liberalistic ideology. This posture has, however, always gone well with requests for more state expenditure or particular benefits for specific sectors of the economy.

If there was a growing elite disquietude with the increasing power of EU over Norwegian affairs, we should expect that this was expressed in an increasing general concern with national self-determination. In 2000 only 27 per cent of the top leaders claimed that national self-determination in Norway was too weak. 15 years later still only 26 per cent of the members of the Norwegian elite groups expressed the same opinion. In other words, there has not been any increase in elite concern about national sovereignty. Eriksen and Fossum (2015) may be right that being associated with EU through the EEA treaty implies a selfinflicted hegemony. The elites themselves seem, however, to express somewhat less apprehension for this situation. This finding raises some doubt whether the declining EU-support can be explained as an expression of an increasing fear of loss of national independence. 
Limited but binding international agreements and treaties constitute another form of supranationality. Figure 2 shows the percentage of all the top leaders who believe that such treaties may weaken the national authority of the parliament and the government.

Figure 2. Can international legislation weaken national authority? Percentages of those who perceive that there is a large possibility for such negative effects.

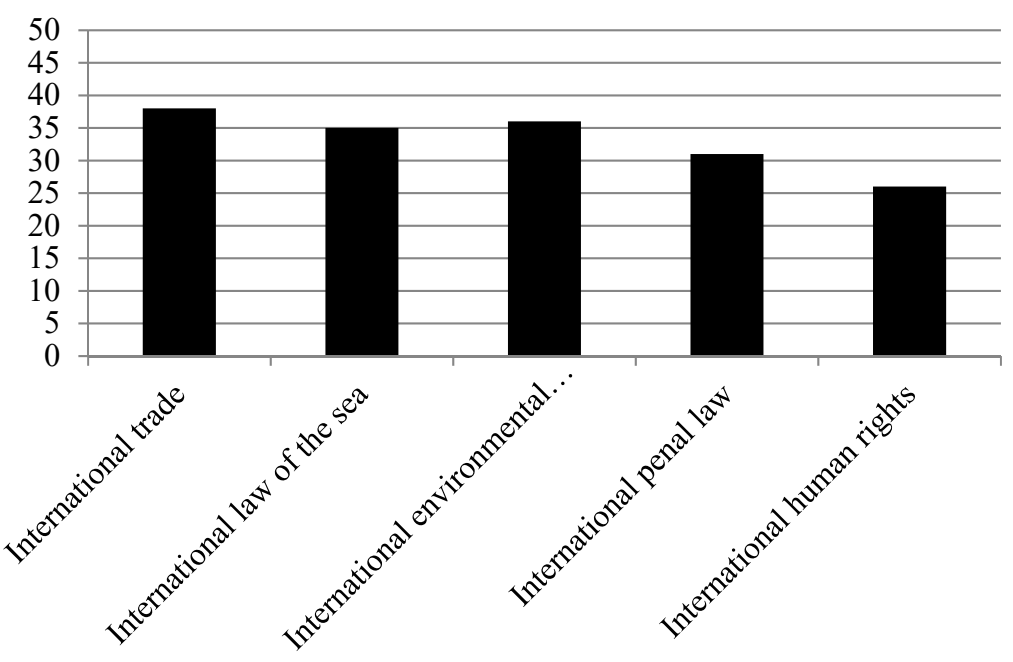

The figure demonstrates that within the five areas there are only minorities who fear that international legislation may undermine the sovereignty of Norwegian political authorities. The Norwegian elites are most reserved with treaties concerning international trade and least worried about international human rights conventions. The main impression of this analysis is that Norwegian elites mainly are positive towards international legislation and treaties. The figure indicates that Norwegian elites in general are more approving of internationalization through such limited treaties and agreements than by entering encompassing supranational organization as EU.

Figure 3 presents the percentage of 'nationalists', i.e. those members of each elite group who across the five areas responded that there is a large possibility that international treaties will undermine national authority. The Figure reveals that in general there are only minorities within each elite group that fear the negative consequences of international legislation on national authority. Judges, senior prosecutors and heads within the police appear as more skeptical than 
the other elite groups. This finding is understandable. It is exactly the agents in the judiciary, particularly the judges, who most directly will experience the limitations which accompany international legislation. They will most often encounter situations where national legislation must give way to international conventions and treaties and where their own decisions are overruled by international courts. Also the mass media elite and church elite stand out as being more reserved with international agreements. In the other end only 11 per cent of the top officers in the military services are afraid that international treaties will impair national independence.

Figure 3. Effects on national authority of international legislation. Percentages of those elite members who perceive that there is a large possibility for negative effects.
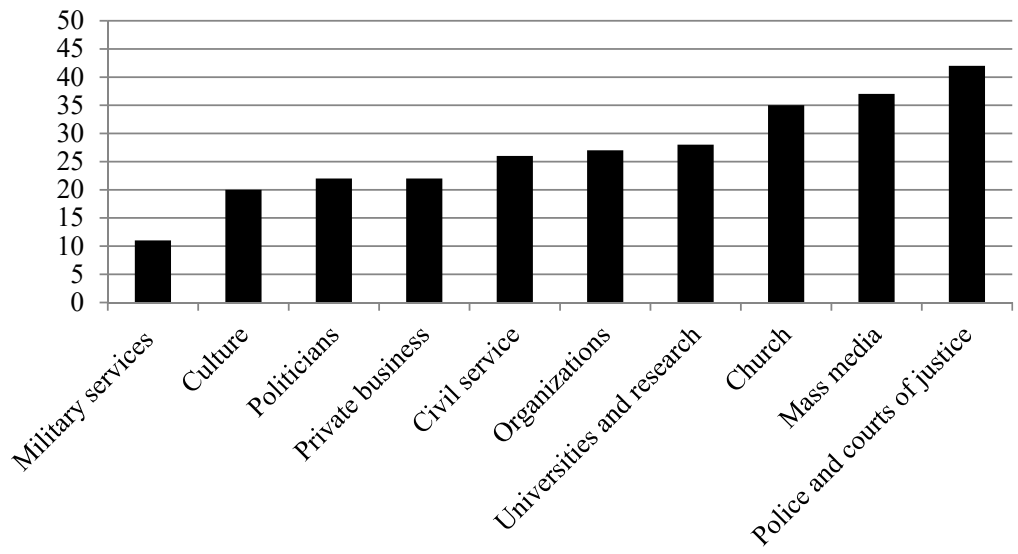

According to the 'judicialization thesis' (see above) politicians should be uncomfortable with the effects of international treaties. Figure 3 shows, however, that politicians in fact constitute one of the least concerned elite groups. Only a minority among them fears that international agreements and treaties will weaken the power of the parliament and the government. However, there are distinct differences between the various political parties. Figure 4 show the percentage 'nationalists' among the politicians within each of the political parties. Few of the politicians belonging to the Socialist Party (SV), the Center Party (SP), the Christian People's Party (KrF), and the Liberal party (Venstre) participated in the Leadership Study 2015. I have nonetheless included politicians from SV and $\mathrm{KrF}$ in Figure 4. 
Figure 4. Effects on national authority of international legislation. Percentages of those among politicians who perceive that there is a large possibility for negative effects.

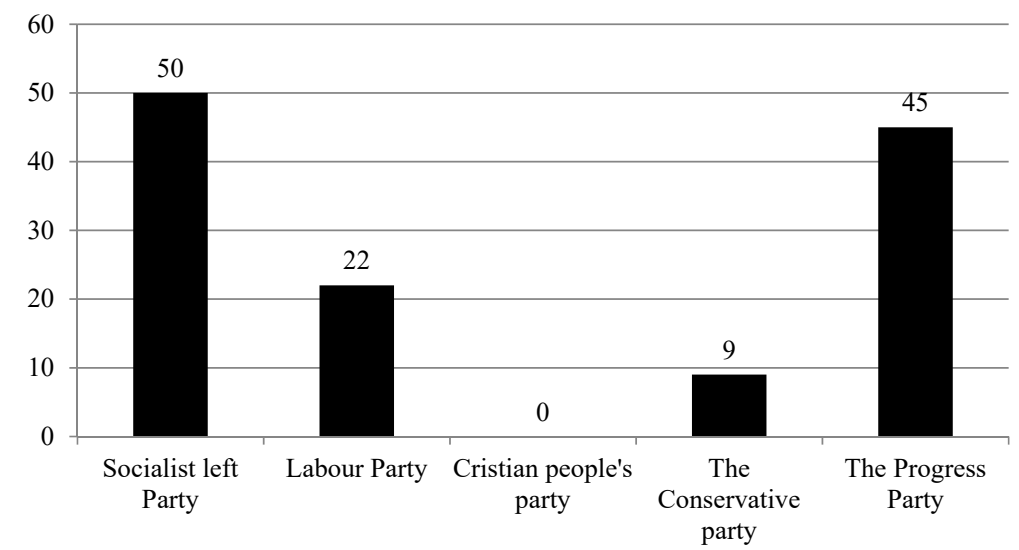

Figure 4 demonstrates that there are two political parties which stand out as 'nationalists' compared to the other parties - Socialist Left Party and the Progress party. 50 and 45 per cent (respectively) of their representatives declare that they fear international agreements may impair the authority of the Norwegian parliament and government. The members of the other parties are predominantly positive to international conventions and treaties.

Previous electoral studies have shown that citizens who voted on SV, in general were positive to an international community with less emphasis on borders. However, when they were asked about signing international agreements the voters of Socialist Left Parties expressed less enthusiasm (Aardal 2007). In other words, the socialist politicians seem to reflect attitudes that are common among their voters. The skepticism of the socialists represents what we may term a 'progressive' nationalism, rooted in an ingrained fear that capitalist interests are dominating international agreements.

The opinions of the politicians from the Progress Party, however, belong to a different set of ideological ideas. Above I showed that the political representatives of the Progress Party defend very strict immigration policies. Their kind of nationalism is of a chauvinist nature, anti-elitist and with significant xenophobic elements (Mudde and Kaltwasser 2012).

Nonetheless, the main picture is that most elite groups in Norway and a majority of the politicians do not fear the consequences of binding international treaties. How can this be explained? I believe the reasons for this posture can 
be found in the character of the relevant international agreements and treaties. Many of them are about attempting to protect essential values and interests, as environmental concerns and human rights, against the unilateral and selfserving actions of strong or authoritarian players on the international scene. These strong players may be big nations or large multinational corporations. Elite support for these international treaties is in line with the present national foreign policy ambition to make Norway a brand for peacemaking, development aid and a better environment.

Some of the treaties primarily regulate the relations between small and big countries in ways that may protect the interests of small countries. An illustration of this aspect of international agreements is the United Nations Convention on the Law of the Sea (UNCLOS) from 1982, a result of the third conference about the law at the sea. Among other things UNCLOS determined that up to 200 nautical miles from the coast a state can create an economic zone, with exclusive right to exploit all natural resources. Coastal States have also rights over their continental shelf, even though it extends more than 200 nautical miles from the coast. These international rules enabled a small country as Norway to take control over the extraction of oil and gas from the North Sea and benefit from the huge incomes which flow from this extraction. In other words, in spite of the binding character of UNCLOS, in the Norwegian case it contributed to strengthen Norwegian sovereignty. Supporting UNCLOS illustrates very well a main strand in Norwegian foreign policy - to seek justice and cooperation in international affairs as protection against the hazards of power politics (Østerud 2007).

Figure 5. International orientation and Norwegian cleavages

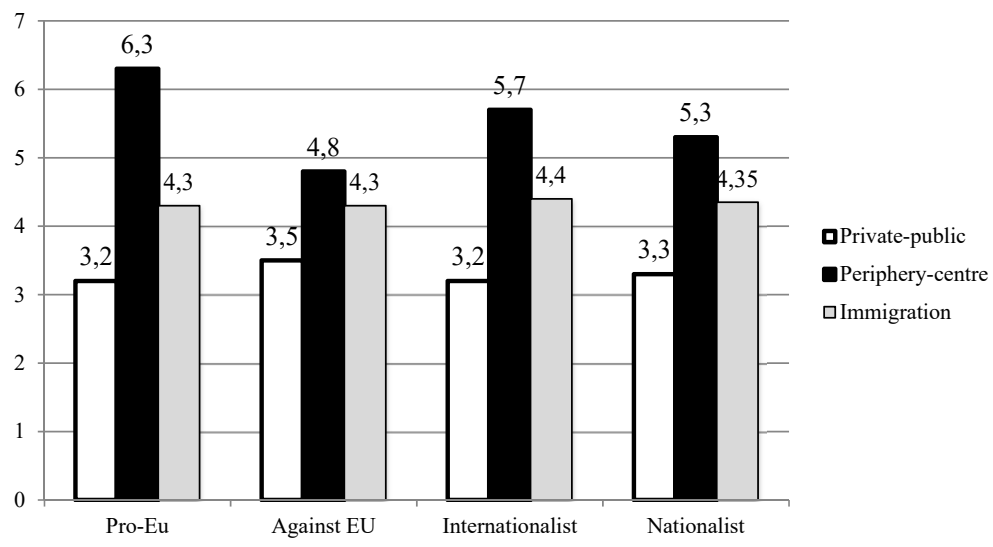


Figure 5 exhibits the relationship between the top leaders' international orientation and their attitudes towards central issues in Norwegian politics. I compare four groups of elite individuals: (1) Pro-EU leaders, (2) leaders who would have voted against EU, (3) 'internationalists', who do not fear that international treaties will weaken national authority, and (4) 'nationalists' who fear such effects. I compare their stance on three basic issues: (1) The conflict between a strong state and more market solutions. (2) How much rural areas shall be supported. (3) Whether it should be easier or more difficult for immigrants to get access to Norway.

Figure 5 reveals that there is only one issue which clearly separates the four groups apart, the extent of support of rural areas, representing the centreperiphery cleavage in Norwegian politics. EU supporters believe on average definitely more than the EU sceptics that central authorities give rural areas too much attention. The differences are much smaller when it comes to endorsing an active state versus leaving more to the private market. EU-opponents are slightly more located to the left in the political landscape than the EU supporters, but the difference is small. With the exception of the politicians from the Socialist Left Party, the private-public cleavage thus seems to be only weakly related to the elites' degree of EU-support and international orientation. In addition, with the exception of the politicians from the Progress Party, differences are negligent in the attitudes towards immigration policies. All four groups are moderately in favor of giving more immigrants' access to Norway.

It is interesting to notice that elite fear of supranationality and skepticism towards EU in general is not coupled with anti-immigration sentiments. Even nationalist oriented elite individuals are reserved against a stricter immigration policy. The problem is the populist Progress Party which, like other populist parties in Europe, nourishes itself from and amplifies a resistance in the population against immigrants from particularly the third world.

\section{DISCUSSION AND CONCLUSION}

The Norwegian society has traditionally had an ambiguous relationship to international cooperation and supranationality. The problematic relation to internationalization has in recent time been most pronounced in connection with the EU issue, the question of whether to join the European Union or not. The EU issue has twice generated a deep division between elites and the population. As a result EU membership is today taken out of Norwegian political discussions.

In general Norwegian elites seem to be positive to international cooperation 
and participation in supranational institutions, whether that is international organizations or agreements. A majority of Norwegian elites does not seem to fear binding international treaties and conventions. Moreover, there is a strong elite consensus on the necessity for a small country to buttress an international legal order to protect against large nations' unilateral exercise of power.

The relationship to the EU is, however, complex. On the one hand, through the EEA Agreement, Norway is obliged to introduce EU directives relating to the internal market in Norwegian law. By adopting these directives Norway has to a large extent been integrated into the European Union, but without co-determination. Accordingly, it would have been better if Norway became a full member of EU. However, the findings reported in this paper indicate that there is a declining support for such a solution. Admittedly, a majority of Norwegian elites would still have voted in favor of joining EU. But the decreasing endorsement of EU membership may be an indication of a growing uneasiness about the relationship to the European Union. The reasons for this uneasiness are not clear. The findings reported above do not indicate that the dominant elites are particular concerned with the lack of co-determination which accompanies the non-member status. The lack of formal access to the decisionmaking arenas within EU is in practice to some extent compensated through informal contacts between EU politicians and EU-officials and their Norwegian colleagues. In addition, the other Nordic countries keep Norwegian authorities well informed on what is going on in EU. These countries also represent an indirect channel of influence in EU matters. I believe the decreasing willingness among Norwegian elites to join EU is more a result of a realistic and pragmatic assessment that Norway manages quite well as a non-member. Moreover, this realism also includes a certainty that the negative opinions in the population forbid any attempt to take up the EU-issue again.

Nonetheless, I guess there will continue to be considerable elite support for $\mathrm{EU}$, for various reasons. Within the private business elite it will still be access to the European markets which counts as the main argument. Within important sections of the political leadership of Norway, particular within the Labor Party, there is also a deep-seated belief that the European Union is a very important European peace project. A testimony of which is that in 2012 the Nobel Peace Prize was awarded to the European Union. Further, while there earlier was a widespread skepticism towards the liberalistic aspect of the union, many opponents have come to acknowledge that the social dimension has gained a stronger place.

The elite opposition to internationalization and supra-nationality has three sources. There is as mentioned above, a socialist resistance, mainly against EU. This resistance seems, however, to be limited. Secondly, a populistic and 
xenophobic nationalism has emerged during the latest decades, first of all promoted and spurred by the right wing Progress Party. This nationalism is not shared by other elites. Thirdly, the main opponents of EU are the defenders of rural interests, and they are primarily represented by the Center Party, with strong ties to the agricultural sector in Norway. These interests are first and foremost against EU. The Center Party is located to the left of center in the political landscape. Nonetheless, in their political language they do not hesitate to use populistic arguments. For instance, representatives of the party frequently set the elites in the capital and the people in the rural areas against each other.

It is striking that the (modest) elite opposition in Norway against internationalization and supranationality is so little related to resistance to immigration. One reason for this situation may be that the rural center/left populism of the Center Party so far has prevented further growth of a right wing populistic nationalism, as represented by the Progress Party.

\section{REFERENCES}

Aardal, B. (ed.) (2003), Velgere i villrede... En analyse av stortingsvalget 2001. Oslo: Universitetsforlaget.

Aardal, B. (2007), Norske velgere. En studie av Stortingsvalget 2005. Oslo: Damm.

Aardal, B. and J. Bergh (eds.) (2015), Valg og velgere. En studie av stortingsvalget 2013. Oslo: Cappelen Damm Akademisk.

Eriksen, Erik O. and John Erik Fossum (eds.) (2015), The European Union's Non-Members. Independence or hegemony? London: Routledge.

Göncz, B. (2017), 'National elites and supranationality'. Paper prepared for the workshop 'Elites in Crisis. Looking Back and Lookin Ahead', May 19-20, Corvinus University of Budapest.

Gulbrandsen, T., F. Engelstad, T.B. Klausen, H. Skjeie, M. Teigen and $\varnothing$. Østerud (2002), Norske makteliter (Norwegian power elites). Oslo: Gyldendal Akademisk.

Mudde, C. and C.R. Kaltwasser (eds.) (2012), Populism in Europe and the Americas. Cambridge: Cambridge University Press.

Rokkan, S. (1987), Stat, nasjon, klasse. Oslo: Universitetsforlaget.

Østerud, Ø., F. Engelstad, and P. Selle (2003), Makten og demokratiet (Power and democracy). Oslo: Gyldendal Akademisk.

Østerud, Ø. (ed.) (2007), Norway in Transition. Transforming a Stable Democracy. London: Routledge. 